University of Nebraska - Lincoln

DigitalCommons@University of Nebraska - Lincoln

Transactions of the Nebraska Academy of

Sciences and Affiliated Societies

Nebraska Academy of Sciences

$9-7-2021$

\title{
Use of Soapweed Yucca (Yucca glauca) by rodents and other vertebrates in western Nebraska
}

\author{
Michael L. Rohde \\ University of Nebraska at Kearney, rohdeml@lopers.unk.edu \\ Keith Geluso \\ University of Nebraska at Kearney, gelusok1@unk.edu \\ Carter Kruse \\ Turner Enterprises, Inc., carter.kruse@retranches.com \\ Mary J. Harner \\ University of Nebraska at Kearney, harnermj@unk.edu
}

Follow this and additional works at: https://digitalcommons.unl.edu/tnas

Part of the Other Ecology and Evolutionary Biology Commons, and the Terrestrial and Aquatic Ecology Commons

Rohde, Michael L.; Geluso, Keith; Kruse, Carter; and Harner, Mary J., "Use of Soapweed Yucca (Yucca glauca) by rodents and other vertebrates in western Nebraska" (2021). Transactions of the Nebraska Academy of Sciences and Affiliated Societies. 533.

https://digitalcommons.unl.edu/tnas/533

This Article is brought to you for free and open access by the Nebraska Academy of Sciences at DigitalCommons@University of Nebraska - Lincoln. It has been accepted for inclusion in Transactions of the Nebraska Academy of Sciences and Affiliated Societies by an authorized administrator of DigitalCommons@University of Nebraska - Lincoln. 


\title{
Use of Soapweed Yucca (Yucca glauca) by rodents and other vertebrates in western Nebraska
}

\author{
Michael L. Rohde, ${ }^{1}$ Keith Geluso, ${ }^{1}$ Carter Kruse, ${ }^{2}$ and Mary Harner ${ }^{1,3}$ \\ 1 Department of Biology, University of Nebraska at Kearney, Kearney, NE 68849 \\ 2 Turner Enterprises, Inc., Bozeman, MT 59718 \\ 3 Department of Communication, University of Nebraska at Kearney, Kearney, NE 68849 \\ Corresponding author — Keith Geluso; 308-865-8982; email gelusok1@unk.edu
}

\begin{abstract}
Soapweed Yucca (Yucca glauca) is a conspicuous and common shrub in the Great Plains of North America, characterized by tall woody flower stalks, large flowers and seed pods, and dense masses of ground-level evergreen leaves. These plant structures can provide a variety of resources or functions to animals. In general, studies focus on single species associated with $Y$. glauca. We examined three groups of vertebrates that interacted with $Y$. glauca and the functions this plant provided for organisms in western Nebraska. We experimentally examined small mammals in areas with and without $Y$. glauca, and we descriptively noted birds and reptiles that used Y. glauca. We documented six mammalian, 13 avian, and four reptilian species using $Y$. glauca for cover, perches, basking sites, homes, and/or nests. We documented a greater species richness and relative abundance of rodents in areas with $Y$. glauca compared to areas without Y. glauca. Deer Mice (Peromyscus maniculatus) showed the greatest difference in relative abundance, with about six times as many individuals in areas with $Y$. glauca (83 individuals) compared to areas without $Y$. glauca (14 individuals). Upon release, a majority of Deer Mice (94\%) ran from trap sites to Y. glauca, as did most other mammalian species. We observed birds mainly perching on flower stalks, as well as a few nesting activities. Soapweed Yuccas provided herpetofauna homes, sites for thermoregulation, perches to watch for predators or prey, and protective cover under leaves. Our findings demonstrated some of the ecological functions for Soapweed Yucca and a variety of vertebrate species using this shrub in grassland ecosystems. Soapweed Yucca is considered a weed in some regions of the Great Plains due to its high abundance in pastures with domestic livestock. On ranches where American Bison (Bos bison) have been reintroduced, individuals consume and actively remove yuccas, especially during winter grazing, and large, multi-headed, aboveground complexes of $Y$.glauca are less common across such ranches. Our study assisted in understanding the role of this native shrub in managed grassland systems.
\end{abstract}

Keywords: Birds, bison, Nebraska, reptiles, rodents, Sandhills, small mammals, Soapweed Yucca, Yucca glauca

DOI: $10.32873 /$ unl.dc.tnas.41.6

\section{Introduction}

Prairies ecosystems of the Great Plains have undergone major degradation during the last century (Samson and Knopf 1994, Samson and Knopf 1996, Knopf and Samson 1997, Samson et al. 2004, Fuhlendorf et al. 2009). For example, $82-99 \%$ of tallgrass prairies and $30-99 \%$ of mixed-grass prairies have been lost throughout the Great Plains of North America (Samson and Knopf 1994). Such changes have caused concomitant declines in numerous animals inhabiting prairies, including birds, mammals, and herpetofauna (Samson and Knopf 1994, Samson and Knopf 1996). One major change to prairies is elimination of North American Bison (Bos bison), a keystone species that formerly roamed widely throughout the region and caused large-scale disturbances but also allowed for regenerative periods in prairie systems (Roe 1970, Moodie and Ray 1976, Shaw 1995, Samson et al. 2004). Throughout the Great Plains, these large native herbivores were replaced mainly with Domestic Cattle (Bos taurus). In recent decades, $B$. bison have been reintroduced on ranches and preserves, in part, to promote and reestablish ecological roles of native ungulates (Knapp et al. 1999, Fuhlendorf et al. 2009). American Bison naturally forage and roam differently across prairie landscapes than Domestic Cattle (Hartnett et al. 1997). However, bison reintroductions generally consist of establishing herds on ranches confined in fences similar to domestic livestock (Bates and Hersey 2016), with fenced bison reusing the same areas frequently unlike free-ranging herds.

Grasses and forbs dominate the prairies of the Great Plains (Weaver 1954, Bleed and Flowerday 1998), but shrubs also have important roles and functions in arid and semi-arid environments (Webber 1953). Soapweed 
Yucca (Yucca glauca) is a common shrub present throughout the Great Plains (Weaver et al. 1956, Keeler et al. 1980). The most conspicuous feature is its rigid, sharpended elongated leaves that form a sphere-shaped mass of dense vegetation at ground level (Kaul et al. 2006). Upper leaves remain green, but as they senesce, leaves bend downward towards the ground forming a broad circular mass that allows for structure and cover throughout the year, potentially benefiting many species. Although generally not a major source of forage for livestock and native ungulates in the Great Plains (Collins 1971, Peden et al. 1974, Peden 1976, Kaul et al. 2006), smaller organisms use different parts of this distinctly shaped perennial plant. For example, masses of linear leaves and flowering stalks provide avian species places to perch, evade predators, nest, and store food; and birds, mammals, and reptiles also use other features of yucca, including eating seeds from pods (e.g., Jones and Droge 1980, Reid and Fulbright 1981, Stormer 1984, Bock and Scharf 1994, Converse and Savidge 2003, White and Geluso 2012). Some species may depend on these grassland shrubs, as Ornate Box Turtles (Terrapene ornata) commonly reside under yucca, where they seek thermoregulatory cover suspected to be linked to population success (Converse and Savidge 2003).

Our study examined a diversity of vertebrates that use $Y$. glauca and the various functions this plant yields for these groups of organisms in western Nebraska. We experimentally examined species richness and relative abundance of small mammals in areas with and without Y. glauca, and we descriptively noted birds and reptiles using Y. glauca. Our study aids in understanding the interactive role of managed American Bison and Domestic Cattle in fenced prairie ecosystems containing this shrub.

\section{Material and Methods}

This study was conducted across western Nebraska in Cherry County (Fawn Lake Ranch, McGinley Ranch, and the Samuel R. McKelvie National Forest, Bessey District, Nebraska National Forest, U.S. Forest Service near Valentine), Keith County (private land), Kimball County (Conservation Reserve Program [CRP] lands), Sheridan County (Deer Creek Ranch), and Thomas County (Nebraska National Forest at Halsey, Bessey District, US Forest Service near Halsey). Sites in Cherry, Keith, Sheridan, and Thomas counties were located in the Sandhill Region of Nebraska, characterized by vast rolling vegetated sand dunes (Bleed and Flowerday 1998). Dominant vegetation at our sites in the Sandhills included Little Bluestem (Schizachyrium scoparium), Sand Bluestem (Andropogon hallii), Switchgrass (Panicum virgatum), American
Plum (Prunus americana), Sand Cherry (Prunus pumillla besseyii), and Y. glauca. Our site in Kimball County was characterized by short-grass prairies with low rolling hills underlain by sedimentary rocks (Maher et al. 2003). Dominant vegetation at this site included Blue Gramma (Bouteloua gracilis), Buffalo Grass (Bouteloua dactyloides), and Y. glauca.

Rodents were trapped from April 2019 to February 2020 at 32 specific sites on four of the properties listed above (Fawn Lake Ranch, Nebraska National Forest at Halsey, Samuel R. McKelvie National Forest, and CRP lands in Kimball County CRP). To determine species richness and relative abundance of rodents, we trapped with Sherman live traps (H. B. Sherman Traps, Inc., Tallahassee, FL) baited with mixed bird seeds. For the yucca (experimental) treatment, we selected locations with Y. glauca. In areas with an abundance of Soapweed Yucca, we set two traps at 10 different yuccas spaced at least $5 \mathrm{~m}$ apart for a total of 20 traps per trap line. Two traps were set at each Soapweed Yucca to ensure that we would account for $Y$. glauca that might harbor several individuals. Each pair of traps was set next to a mature single or multi-headed complex of $Y$. glauca. A yucca complex reflects asexual reproduction through rhizomes and budding mechanisms, as an individual plant develops with multiple rosettes and rhizomatous clones to form multi-headed, aboveground complexes (Weaver et al. 1956, Bonner and Karrfalt 2008). Such a mechanism is important to yucca, as little rain is usually available for germination of seeds in the arid and semi-arid environments in which it resides. Larger complexes yield more aboveground biomass with more cover structure for small vertebrates.

For the non-yucca (control) treatment, we located areas at least $30 \mathrm{~m}$ away from yucca treatments that generally lacked $Y$. glauca or contained small or a few individuals. For many sites, non-yucca and yucca trap lines were in the same pasture. For a few sites, trap lines were in adjacent pasture, such as on the other side of a fence or roadway. For control trap lines, we attempted to replicate the same slope, aspect, and elevation as the nearby experimental trap line. We again set pairs of traps spaced at least $5 \mathrm{~m}$ apart for a total of 20 traps at each site. Pairs of traps were set similarly to experimental trap lines surrounded by various grasses and forbs but lacking $Y$. glauca. We initially set the first few control trap lines at about $30 \mathrm{~m}$ away from experimental trap lines. However, we moved them farther away once we observed that some rodents traveled distances $>30 \mathrm{~m}$ to find cover in Y. glauca in experimental trap lines.

We set traps in the evening and checked them the following morning. Each site with a yucca and non-yucca 
Table 1. Numbers and species of small mammals captured in areas with Soapweed Yuccas (Yucca glauca) and areas generally lacking Y. glauca at sites across western Nebraska, April 2019 - February 2020. Asterisk represents $\mathrm{P}<0.001$.

\begin{tabular}{llccc} 
Species & Common name & Yucca & Non-Yucca & Total \\
\hline Peromyscus maniculatus & Deer Mouse & $83^{*}$ & $14^{*}$ & 97 \\
Perognathus flavescens & Plains Pocket Mouse & 39 & 31 & 70 \\
Dipodomys ordii & Ord's Kangaroo Rat & 33 & 11 & 44 \\
Reithrodontomys megalotis & Western Harvest Mouse & 10 & 7 & 17 \\
Microtus ochrogaster & Prairie Vole & 5 & 3 & 8 \\
Onychomys leucogaster & Northern Grasshopper Mouse & 3 & 3 & 6 \\
Chaetodipus hispidus & Hispid Pocket Mouse & 1 & 0 & 1 \\
\hline Totals & & $\mathbf{1 7 4}^{*}$ & $\mathbf{6 9}^{*}$ & $\mathbf{2 4 3}$
\end{tabular}

trap line was trapped only once during the project. Individuals were not marked. For each individual captured, we recorded species, sex, age, and reproductive status. Upon release from traps in experimental treatments, we attempted to follow most individuals to escape structures or holes and recorded the type of retreat, as we were interested in whether individuals used Y. glauca. We also measured the distance from where the individuals were captured in traps to such retreats, if they were observed. We recorded other information about retreats, such as if it was a clump of grass, another species of shrub, hole created by an Ord's Kangaroo Rat (Dipodomys ordii), or runway of a Prairie Vole (Microtus ochrogaster). We occasionally noted escape structures and distances to structures on control lines.

While trapping rodents, driving between sites on ranches associated with this research, and conducting other research in the region, we also recorded opportunistic observations of birds and herpetofauna interacting with Y. glauca. For these individuals, we recorded the function of use, such as nesting and perching, as well as what part of the $Y$. glauca was being used, that is, stalk, leaf-less stem, or basal mass of leaves. We recorded opportunistic observations of birds and herpetofauna from April 2019 to July 2020.

We used Mann-Whitney U tests to examine differences between treatments for species richness and total number of captures of all rodents on trap lines. Similar analyses were run individually for the three species of rodents with the most overall captures. We also ran another Mann-Whitney $U$ test on all rodents combined, excluding Peromyscus maniculatus, to examine whether the other species with fewer captures showed the same trend in abundance between the two treatments or whether Peromyscus maniculatus was driving the overall pattern of all species combined. Descriptive statistics were summarized for escape distances.

\section{Results}

At 32 trapping sites, we captured a total of 243 rodents of seven species (Table 1). Overall, we observed a similar number of total species (i.e., species richness) across all sites in areas with yucca (7 species) and without (6 species) Y. glauca (Table 1). However, we detected more species (median $=2$ species) on trap lines with yuccas compared trap lines without yuccas (median $=1$ species; $\mathrm{P}=$ $0.004, Z=2.92$ ). We detected a difference in overall relative abundance between treatments, with more rodents captured per trap line in areas with yuccas (median $=5$ individuals) compared to areas without yuccas (median $=1.5$ individuals; $\mathrm{P}<0.001, \mathrm{Z}=3.51$; Table 1 ) in our short trap lines. For the three species most frequently captured, we detected that the Deer Mouse (Peromyscus maniculatus; $\mathrm{P}<0.001, \mathrm{Z}=4.16$ ) was the only species more abundant in areas with Y. glauca (median $=2$ individuals) compared to areas without $Y$. glauca (median $=0$ individuals; Table 1). We did not detect a difference in relative abundance for Ord's Kangaroo Rats $(P=0.45, Z=0.75)$ and Plains Pocket Mice (Perognathus flavescens) between treatments $(P=0.55, Z=0.6)$. For the relative abundance of all species combined excluding Deer Mice, we detected more individuals in areas with yuccas (median $=3$ individuals) compared to areas without yuccas (median $=1$ individual; $\mathrm{P}=0.049, \mathrm{Z}=1.97$ ).

Six of seven rodent species used ground-level leaf masses of $Y$. glauca or holes below these shrubs for protective cover. A Hispid Pocket Mouse (Chaetodipus hispidus) was captured adjacent to a Y. glauca, but we did not have direct observations of the species interacting with the plant. Upon release from trap sites, $94 \%$ of Deer Mice in experimental treatments (68 of 72 observations) ran to a $Y$. glauca, three ran into holes not associated with $Y$. glauca, and one ran into a runway constructed by a Prairie Vole. In areas without Y. glauca on control trap lines, 
Deer Mice used bunch grasses, Sand Cherries, and holes of Ord's Kangaroo Rats as escape structures up to $42 \mathrm{~m}$ from traps. One Deer Mouse traveled over $30 \mathrm{~m}$ from the control trap line to a Y. glauca in the experimental trap line early in the project. In experimental trap lines, Deer Mice traveled an average ( \pm SD) of 1.9 (3.1) m (median $0 \mathrm{~m}$, range $=0-14 \mathrm{~m}$ ) to $Y$. glauca. A distance of $0 \mathrm{~m}$ represented rodents that used the $Y$. glauca around which traps were set.

We documented 10 escape structures for Ord's Kangaroo Rats; nine were associated with Y. glauca, and another was a hole constructed by a kangaroo rat away from Y. glauca. The nine associated with Y. glauca represented kangaroo rat holes dug under these shrubs, many on slopes, with five of these holes under Y. glauca adjacent to traps $(0 \mathrm{~m})$, whereas the others were $12,12,15$, and 20 $\mathrm{m}$ away from traps (average $\pm \mathrm{SD}=6.6 \pm 8.1 \mathrm{~m}$, median $=0 \mathrm{~m}$ ). Upon release, most Ord's Kangaroo Rats located one of their runways and ran quickly out of view.

Of 22 escape structures for Plains Pocket Mice on experimental trap lines, 59\% (13 of 22) were associated with Y. glauca, whereas $41 \%$ (9 of 22) were in holes in the ground away from yuccas, including one hole constructed by an Ord's Kangaroo Rat. Seven Y. glauca were adjacent to traps $(0 \mathrm{~m})$, whereas others were $3,6,7,7,9$, and $13 \mathrm{~m}$ away (average $\pm \mathrm{SD}=3.5 \pm 4.4 \mathrm{~m}$, median $=0 \mathrm{~m}$ ). Some individuals entered the basal mass of leaves, but others entered holes in the sand that went under yuccas.

For less frequently captured species, all escape structures of Western Harvest Mice (Reithrodontomys megalotis) were in basal leaves of yuccas adjacent to traps. For Prairie Voles, two individuals entered leaves of adjacent yuccas, and one individual ran into a vole run and disappeared. For Northern Grasshopper Mice (Onychomys leucogaster), two individuals entered basal masses of leaves of Y. glauca, one adjacent to traps and one $7 \mathrm{~m}$ away. Another Northern Grasshopper Mouse entered a hole not associated with Y. glauca.

We documented 13 avian species using Y. glauca, with most individuals perching (92\%) and a few nesting (8\%; Figure 1; Table 2). Most birds perched on flower stalks $(96 \%)$, but one individual perched on a thick leafless stem $(2 \%)$, and another perched on a dead mass of leaves (2\%; Table 2). From perches, individuals sang (Figure 1), watched for predators, and sought out insects.

We documented four species of reptiles interacting with Y. glauca: Common Lesser Earless Lizard (Holbrookia maculata), Prairie Lizard (Sceloporus consobrinus), Ornate Box Turtle, and Bullsnake (Pituophis catenifer sayi). While on experimental treatments, we observed 10 reptiles in areas with $Y$. glauca compared to two reptiles in areas without $Y$. glauca. Interactions with $Y$. glauca appeared to consist of plants used for homes, basking sites for thermoregulation, perches to watch for predators or prey, and protective cover associated with the basal mass of leaves (Figure 1).

\section{Discussion}

Numerous studies have documented how single vertebrate species interact with the nearly 30 species of Yucca (Bonner and Karrfalt 2008) that occur across western North America and the West Indies (e.g., Allen 1968, Jones and Droge 1980, Reid and Fulbright 1981, Bock and Scharf 1994, Kozma and Mathews 1997, Higgenbotham et al. 2000, Converse and Savidge 2003, Montoya et al. 2004, White and Geluso 2012). However, to our knowledge, this is the first study documenting a variety of vertebrate species and multiple types of interactions associated with a single species of yucca ( $Y$. glauca), although one paper describes mainly insect interactions and five vertebrate species with Yucca elata (Campbell and Keller 1932). We observed a total of 23 species of vertebrates (six mammals, 13 birds, and four herpetofauna) interacting with Y. glauca, many likely representing the first published association with the plant. With more effort and other sampling approaches, like use of camera traps and uncovering basal leaf masses, certainly more species of vertebrates could be documented associated with Y. glauca throughout its broad geographic distribution. This shrub provides some of the most abundant vertical structures and evergreen foliage for vertebrates to use in prairie ecosystems of North America. As described by Webber (1953), each yucca gradually changes its immediate surrounding until a small community of its own is created, consisting of small plants, rodents, insects and birds, that would not exist without protection from the yucca.

In western Nebraska, Y. glauca served a number of functions for small mammals. Basal masses of leaves provided places for rodents to live and cover to escape from predators. Most Deer Mice released from traps ran into $Y$. glauca, sometimes not the nearest yucca, and quickly disappeared in what appeared to be a specific plant. These yuccas likely were the daytime home for these nocturnal rodents, especially those individuals that did not run into the closest yucca. Use of yuccas as houses is known for other small mammals, such as woodrats (Neotoma; Thies and Caire 1990, Smith 1995). Many Deer Mice and individuals of other species entered the closest Y. glauca to the pair of traps, which could represent a daytime retreat, but more likely individuals were seeking the nearest protective cover. These animals entered the masses of pointed sharp leaves, but did not disappear within, as we could visually see individuals as they remained motionless, 


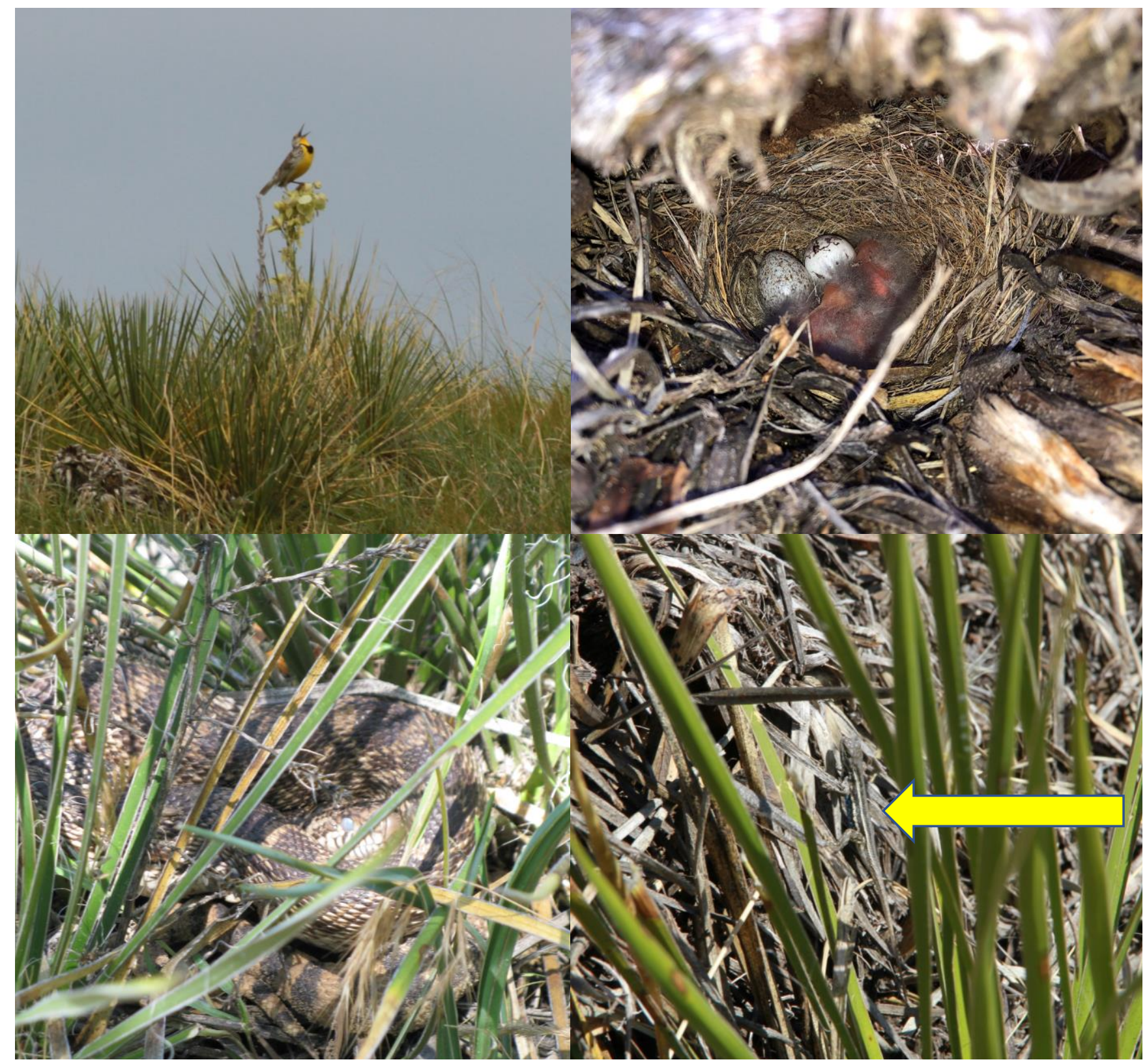

Figure 1. Examples of vertebrates associated with Soapweed Yucca (Yucca glauca) in western Nebraska. Upper left panel represents a Western Meadowlark (Sturnella neglecta) singing from atop a blooming flower stalk. Upper right panel represents a Lark Sparrow (Chondestes grammacus) nest with nestlings, an egg (top center), and an egg (left side of nest) of a Brown-headed Cowbird (Molothrus ater). Lower left panel represents a Bullsnake (Pituophis catenifer sayi) in the state of ecdysis, as scales covering eyes were cloudy, a step in the process of shedding skin (Photograph by Ashley Forrester). Lower right panel represents a Prairie Lizard (Sceloporus consobrinus) in the center camouflaged on dead leaves of Y. glauca.

suggesting this was not a home. We also observed runways of Prairie Voles entering and exiting the vegetative basal leaf mass of multiple $Y$. glauca, potentially representing both protective cover and a home, similar to that of Yellow-nosed Cotton Rats (Sigmodon ochrognathus) in Arizona (Hoffmeister 1959). On many occasions, although not recorded quantitatively, we observed the conspicuous round horizontal holes of Ord's Kangaroo Rats excavated below Y. glauca on hillsides, with distinctive runways leading to openings. Yuccas certainly provide other functions for small mammals besides those we observed, such as food resources and housing materials (Riegel 1942, Dial 1988, Vander Wall et al. 2006, Sanford and Huntly 2009). We suspect many granivorous species 
Table 2. Species, numbers of observations, types of interactions, and parts of Soapweed Yucca (Yucca glauca) that birds interacted with in western Nebraska, April 2019 - July 2020. "Stalk" represents the tall woody flower stalk associated with sexual reproduction of Y. glauca.

\begin{tabular}{lllll} 
Species & Common name & Number & Interaction type & Part of yucca \\
\hline Sturnella neglecta & Western Meadowlark & 16 & Perch & Stalk \\
Chondestes grammacus & Lark Sparrow & 8 & Perch; nest & Stalk, stem ${ }^{\text {a; leaves }}$ \\
Agelaius phoeniceus & Red-winged Blackbird & 6 & Perch & Stalk \\
Toxostoma rufum & Brown Thrasher & 3 & Perch & Stalk \\
Ammodramus savannarum & Grasshopper Sparrow & 3 & Perch & Stalk \\
Tyrannus verticalis & Western Kingbird & 2 & Perch & Stalk \\
Molothrus ater & Brown-headed Cowbird & 1 & Nest $^{\text {b }}$ & Leaves \\
Zenaida macroura & Mourning Dove & 1 & Perch & Stalk \\
Spiza americana & Dickcissel & 1 & Perch & Stalk \\
Sayornis saya & Say's Phoebe & 1 & Perch & Stalk \\
Spizella pusilla & Field Sparrow & 1 & Perch & Stalk \\
Buteo jamaicensis & Red-tailed Hawk & 1 & Perch & Leaves \\
Icterus spurius & Orchard Oriole & 1 & Perch & Stalk \\
& Unknown galliform & 1 & Nest & Leaves \\
& Unknown sparrow & 3 & Perch; nest & Stalk; leaves \\
\hline
\end{tabular}

aStem represented exposed thick, leaf-less stump-like mass.

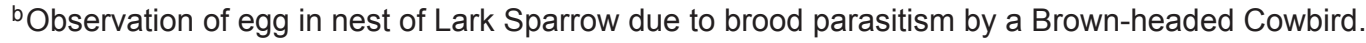

in the Sandhills of Nebraska also feed on yucca seeds (White and Geluso 2012), although this was beyond the realm of our current study.

For birds, perching was the most frequent interaction observed with Y. glauca, accounting for about $92 \%$ of avian observations. In most areas, flower stalks represented the tallest and most rigid structure to alight upon in grassland habitats, with all but two of our perching observations on tall woody flower stalks. Birds have been shown to perch on tall dead structures in environments for good views to avoid predators and to observe and seek out prey (Becker et al. 2009). One exception was a Red-tailed Hawk (Buteo jamaicensis) that perched atop a dead rounded mass of leaves late in the evening. Perching upon flower stalks represents potentially a reproductive behavior or a protective vantage point. We observed many individuals from afar singing from these high lookout points to attract mates and defend/establish territories, as species such as Western Meadowlarks (Sturnella neglecta) select the most elevated perches to sing (Figure 1; Castrale 1983). Conspicuousness of perches and visibility of singing birds might also be important for perch selection to engage in territorial song display (Castrale 1983). While walking across grasslands, we flushed birds that then alighted on yucca flower stalks away from us to watch safely from afar. We observed flower stalks also used for sit-and-wait predatory behaviors of Say's
Phoebes (Sayornis saya), as individuals watched for flying insects from such perches. Lastly, Lark Sparrows (Chondestes grammacus) and an unknown galliform constructed nests within the protective ground-level masses of leaves (Figure 1). An egg of a Brown-headed Cowbird (Molothrus ater) also was observed in a Lark Sparrow nest (Figure 1). Other single-species studies previously have observed some of these types of interactions with various species of yuccas (Becker et al. 2009, Bock and Scharf 1994, Montoya et al. 2004, Rodríguez-Estrella 2000). We suspect that none of these bird species are dependent on yuccas in the region, and pastures with fewer yuccas would not limit their occurrence in the area. An experimentally designed study would be needed to examine whether pastures with and without yuccas affect relative abundance of birds.

Herpetofauna used Y. glauca as places for homes, thermoregulation, perches, and protective cover. Most Prairie Lizards appeared to live within Y. glauca, especially larger complexes with one or more bare roots or stems lacking leaves due to fire, death, wind, or disturbance. Sand frequently is blown away from thick underground stems (i.e., roots; Weaver et al. 1956). We seldom observed individuals far from Y. glauca, as researchers have shown Prairie Lizards rarely to be in open habitats but frequently associated with biotic structures such as Y. glauca (Dixon and Medica 1966, Jones and Droge 
1980). In fact, one species of lizard in Baja California is known only to live on a single species of yucca (Bezy et al. 2008). An experimental investigation on the abundance of Prairie Lizards in areas with and without Soapweed Yucca is warranted to determine whether an absence of yucca would limit the presence or abundance of this lizard in the region. Some Prairie Lizards basked on leafless thick stems or roots, which were dark vertical structures, that likely provided a substrate for thermoregulation. Maintaining temperatures exposed in a specific narrow range for reptiles optimizes many physiological processes, such as rate and efficiency of digestion, energy acquisition, and reproduction (Hammond et al. 1988, Carriére et al. 2008). These sites also likely provided vantage points for lizards to watch for prey, similar to other Sceloporus lizards (Lemos-Espinal et al. 2003). We observed Common Lesser Earless Lizards and a Bullsnake within basal masses of leaves that provided protective cover. Common Lesser Earless Lizards occur in open habitats but also are associated in habitats containing Y. glauca (Jones and Droge 1980). The Bullsnake remained in a Y. glauca for a few days in a state of ecdysis, as scales covering its eyes were cloudy (Figure 1). This step generally indicates the shedding of their skin is days away. When eyes are cloudy or opaque, snakes have impaired vison that likely increases susceptibility to predation (King and Turmo 1997). It is unclear whether our observation of an Ornate Box Turtle under the mass of leaves from a Y. glauca represented use as protection or thermoregulation, but this species is known to use Y. glauca for thermoregulatory purposes (Converse et al. 2002, Converse and Savidge 2003).

More remains to be understood about what influences abundance of $Y$. glauca and the plant's ecological roles in prairie ecosystems in North America. Yucca abundance in the Great Plains prior to European settlement is unknown, but today Soapweed Yucca generally is considered to increase when pastures are grazed only in summer (Dunn et al. 2017). As a result, this native shrub often is treated as a weed or noxious plant, being eradicated and/or controlled with herbicides or mechanical means in some areas (Weaver et al. 1956, Bovey 1964, Collins 1971, Sosebee et al. 1982, Kaul et al. 2006, Fick and Harmoney 2019). Cattle generally do not eat yucca during the warm growing season, except for browsing on flowers for a short time in spring (Collins 1971, Stubbendieck et al. 1989, Kerley et al. 1993, Kaul et al. 2006). Winter or dormant season grazing of Y. glauca by Domestic Cattle does occur and can control yucca proliferation (Fick and Harmony 2019), but wintertime, open range grazing by Domestic Cattle in the Sandhills is relatively uncommon. On ranches where American Bison have been reintroduced, bison management typically includes winter grazing on open range where individuals readily consume and actively remove yuccas, reducing the abundance of large, multi-headed, aboveground yucca complexes across entire ranches. Fence line contrasts in abundance of Y. glauca between American Bison ranches and Domestic Cattle ranches are often strikingly obvious (Figure 2; K. Geluso and C. Kruse, personal observation). Removal and consumption by bison or mechanical and chemical removal by humans yield positive direct benefits for bison and cattle, as research shows that removal of Y. glauca increases herbaceous forage for grazers (Sosebee et al. 1982). However, our study suggests that the direct and indirect effects of yucca on landscapes due to various interactions with vertebrates is measurable and likely of ecological consequence. As one example, both Deer Mice and Ord's Kangaroo Rats exhibit scatter-hoarding behaviors (Vander Wall 1997, Vander Wall et al. 2001, White and Geluso 2012). Scatter-hoarding rodents place small quantities of various types of seeds throughout territories in shallow pits, effectively dispersing seeds and enhancing reproductive success of plants (Vander Wall 1993). An abundance of such rodents likely benefits other grassland plants, including species used as livestock forage, as well as continued propagation of yuccas, in prairie ecosystems. Our study demonstrated many interactions this native shrub species has with vertebrate fauna in western Nebraska and helps to assist in understanding the role of yuccas in managed grassland systems.

Acknowledgments - We thank Turner Enterprises, Inc. for providing housing and the opportunity to conduct this study in the Nebraska Sandhills while on Deer Creek, Fawn Lake, and McGinley ranches. Tom Bragg, Ben Davis, John Halstead, and Chris Redman provided field and logistical support while on Turner ranches. Greg Wright and Julie Bain (USFS) assisted with Special Use Permits to work on U.S. Forest Service Lands. Skyler Smith and Tony Long assisted with field aspects of this research. Ashley Forrester provided the Bullsnake observation. The Department of Biology, University of Nebraska at Kearney, assisted with logistical support and vehicles. The Program of Excellence Committee in the Department of Biology awarded financial support for this research. The Institutional Animal Care and Use Committee at the University of Nebraska at Kearney approved all parts of the proposed investigation with vertebrates before the project was undertaken. We would like to recognize that our research was conducted on the traditional native lands of the Sioux, Pawnee, and Cheyenne tribes. 

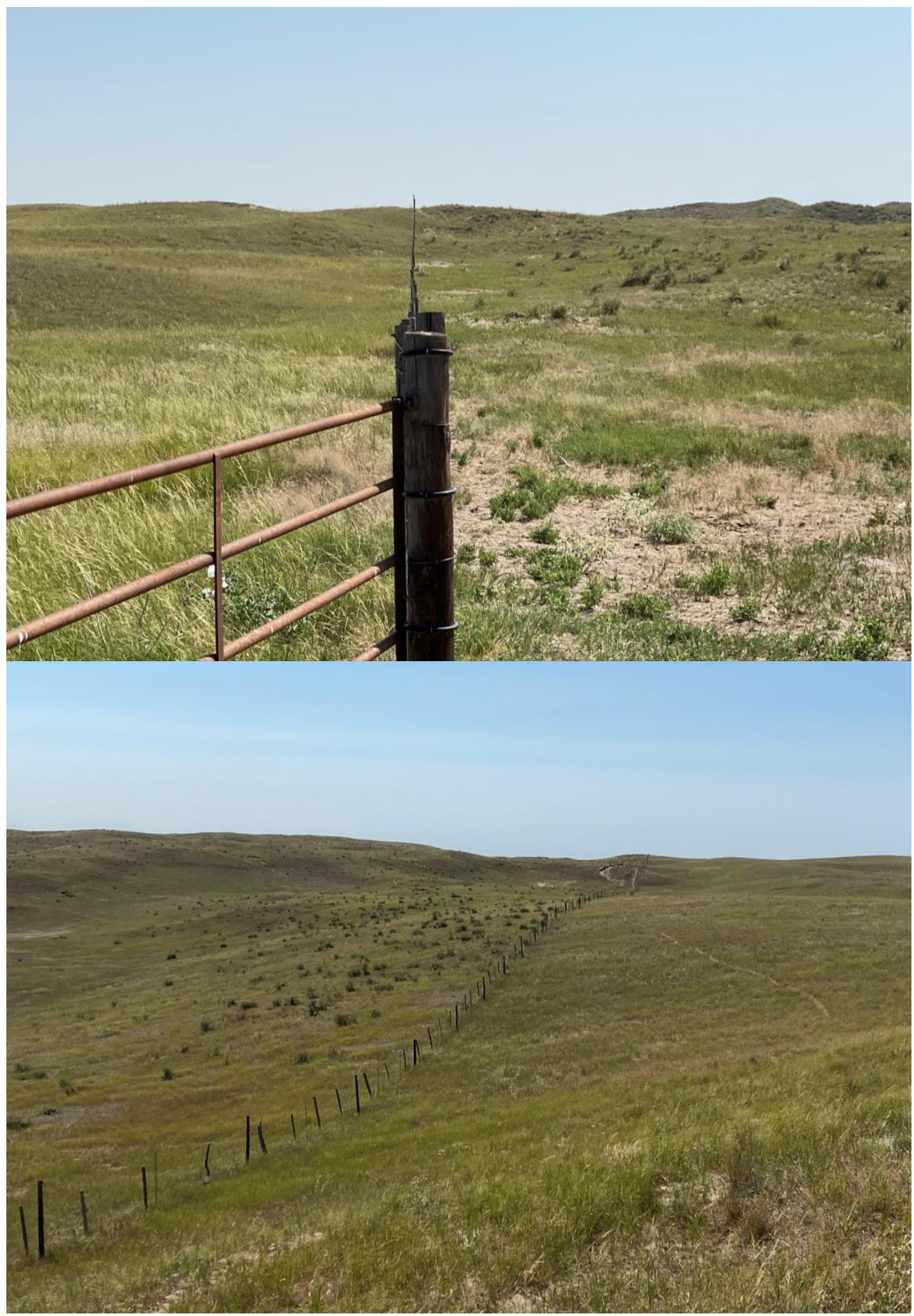

Figure 2. Fence line contrasts in the abundance of Soapweed Yucca (Yucca glauca) between pastures grazed by American Bison (Bos bison) and Domestic Cattle (Bos taurus) in the Sandhill Region of Nebraska. Top photograph, bison ranch on left side and cattle ranch on right side, Cherry County, Nebraska (Photograph by Chris Redman). Bottom photograph, cattle ranch on left side and bison ranch on right side, Garden County, Nebraska (Photograph by Tyrell Anderson). 


\section{Literature Cited}

Allen EO. (1968) Range use, foods, condition, and productivity of White-tailed Deer in Montana. Journal of Wildlife Management 32: 130-141.

Bates B, and Hersey K. (2016) Lessons learned from bison restoration efforts in Utah on western rangelands. Rangelands 38: 256-265.

Becker ME, Bednekoff PA, Janis MW, and Ruthven DC III. 2009. Characteristics of foraging perch-sites used by Loggerhead Shrikes. Wilson Journal of Ornithology 121: 104-111.

Bezy RL, Bezy KB, and Bolles K. (2008) Two new species of night lizards (Xantusia) from Mexico. Journal of Herpetology 42: 680-688.

Bleed AS, and Flowerday CA. (1998) An atlas of the Sandhills. $3^{\text {rd }}$ Edition. Resource Atlas No. 5b. Conservation and Survey Division, Institute of Agriculture and Natural Resources, University of Nebraska-Lincoln, Lincoln, NE. 260 pp.

Bock CE, and Scharf WC. (1994) A nesting population of Cassin's Sparrows in the Sandhills of Nebraska. Journal of Field Ornithology 65: 472-475.

Bonner FT, and Karrfalt RP. (2008) The woody plant seed manual. U.S. Department of Agriculture, Forest Service, Agriculture Handbook 727. 1228 pp.

Bovey RW. (1964) Control of yucca by aerial application of herbicides. Journal of Range Management 17: 194-196.

Campbell RS, and Keller JG. (1932) Growth and reproduction of Yucca elata. Ecology 13: 364-374.

Carriére M, Rollinson N, Suley AN, and Brooks RJ. (2008) Thermoregulation when a growing season is short: sexbiased basking patterns in a northern population of Painted Turtles (Chrysemys picta). Journal of Herpetology 42: 206-209.

Castrale JS. (1983) Selection of song perches by sagebrushgrassland birds. Wilson Bulletin 95: 647-655.

Collins B. (1971) Yucca: friend or foe on Texas rangelands. Cattleman 57: 63-64.

Converse SJ, Iverson JB, and Savidge JA. (2002) Activity, reproduction and overwintering behavior of Ornate Box Turtles (Terrapene ornata ornata) in the Nebraska Sandhills. American Midland Naturalist 148: 416-422.

Converse SJ, and Savidge JA. (2003) Ambient temperature, activity, and microhabitat use by Ornate Box Turtles (Terrapene ornata ornata). Journal of Herpetology 37: 665-670.

Dial KP. (1988) Three sympatric species of Neotoma: dietary specialization and coexistence. Oecologia 76: 531-537.

Dixon JR, and Medica PA. (1966) Summer food of four species of lizards from the vicinity of White Sands, New Mexico. Los Angeles County Museum of Natural History, Contributions in Science 121: 1-6.
Dunn CD, Stephenson MB, and Stubbendieck J. (2017) Common forbs and shrubs of Nebraska: rangeland, prairie, and pasture. University of Nebraska-Lincoln Extension Publication EC118, Institute of Agriculture and Natural Resources, Lincoln, NE. 260 pp.

Fick WH, and Harmoney K. (2019) Great Plains Yucca (Yucca glauca) control on shortgrass rangelands. Weed Technology 33: 192-195.

Fuhlendorf SD, Engle DM, Kerby J, and Hamilton R. (2009) Pyric herbivory: rewilding landscapes through the recoupling of fire and grazing. Conservation Biology 23: 588-598.

Hammond KA, Spotila JR, and Standora EA. (1988) Basking behavior of the turtle Pseudemys scripta: effects of digestive state, acclimation temperature, sex, and season. Physiological Zoology 61: 69-77.

Hartnett DC, Steuter AA, and Hickman KR. (1997) Comparative ecology of native versus introduced ungulates. In FL. Knopf and FB. Samson (Editors), Ecology and conservation of Great Plains Vertebrates, pp. 72-101. (New York, NY: Springer-Verlag)

Higginbotham JL, Dixon MT, and LK Ammerman. (2000) Yucca provides roost for Lasiurus xanthinus (Chiroptera: Vespertilionidae) in Texas. The Southwestern Naturalist 45: 338-340.

Hoffmeister DF. (1959) Distributional records of certain mammals from southern Arizona. The Southwestern Naturalist 4: 14-19.

Jones SM, and Droge DL. (1980) Home range size and spatial distributions of two sympatric lizard species (Sceloporus undulatus, Holbrookia maculata) in the Sand Hills of Nebraska. Herpetologica 36: 127-132.

Kaul RB, Sutherland DM, and Rolfsmeier SB. (2006) The Flora of Nebraska (Lincoln, NE: School of Natural Resources, Conservation and Survey Division, Institute of Agriculture and Natural Resources, University of Nebraska-Lincoln).

Keeler KH, Harrison AT, and Vescio LS. (1980) Flora and Sandhills prairie communities of Arapaho Prairie, Arthur County, Nebraska. The Prairie Naturalist 12: 65-78.

Kerley GIH, Tiver F, and Whitford WG. (1993) Herbivory of clonal populations: cattle browsing affects reproduction and population structure of Yucca elata. Oecologia 93: 12-17.

King RB, and Turmo JR. (1997) The effects of ecdysis on feeding frequency and behavior of the Common Garter Snake (Thamnophis sirtalis). Journal of Herpetology 31: 310-312.

Knapp AK, Blair JM, Briggs JM, Collins SL, Hartnett DC, Johnson LC, and Towne EG. (1999) The keystone role of Bison in North American tallgrass prairie. BioScience 49: 39-50.

Knopf FL, and Samson FB. (1997) Conservation of grassland vertebrates. In FL. Knopf and FB. Samson (Editors), 
Ecology and Conservation of Great Plains Vertebrates, Ecologcial Studies 125, pp. 273-289. (New York, NY: Springer-Verlag)

Kozma JM, and Mathews NE. (1997) Breeding bird communities and nest plant selection in Chihuahuan Desert habitats in south-central New Mexico. Wilson Bulletin 109: 424-436.

Lemos-Espinal JA, Smith GR, Ballinger RE, and Smith HM. (2003) Ecology of Sceloporus undulatus speari (Sauria: Phrynosomatidae) from north-central Chihuahua, México. Journal of Herpetology 37: 722-725.

Maher HD Jr, Engelmann GF, and Shuster RD. 2003. Roadside Geology of Nebraska (Missoula, MT: Mountain Press Publishing Company).

Montoya AB, Zwank PJ, and Cardenas M. (1997) Breeding biology of Aplomado Falcons in desert grasslands of Chihuahua, Mexico. Journal of Field Ornithology 68: 135-143.

Moodie DW, and Ray AJ. (1976) Buffalo migration in the Canadian plains. Plains Anthropologist 21: 45-52.

Peden DG. (1976) Botanical composition of Bison diets on shortgrass plains. The American Midland Naturalist 96: 225-229.

Peden DG, Van Dyne GM, Rice RW, and Hansen RM. (1974) The trophic ecology of Bison bison L. on shortgrass plains. Journal of Applied Ecology 11: 489-497.

Reid WH, and Fulbright HJ. (1981) Impaled prey of the Loggerhead Shrike in the northern Chihuahuan Desert. The Southwestern Naturalist 26: 204-205.

Riegel A. (1942) Some observations of the food coactions of rabbits in western Kansas during periods of stress. Transactions of the Kansas Academy of Science 45: 369-375.

Rodríguez-Estrella R. (2000) Breeding success, nest-site characteristics, and diet of Swainson's Hawk (Buteo swainsoni) in a stable population in northern México. Canadian Journal of Zoology 78: 1052-1059.

Roe FG. (1970) The North American Buffalo: a Critical Study of the Species in its Wild State. 2nd Edition (Toronto, Canada: University of Toronto Press).

Samson F, and Knopf F. (1994) Prairie conservation in North America. BioScience 44: 418-421.

Samson FB, and Knopf FL. (1996) Prairie Conservation: Preserving North America's Most Endangered Ecosystem (Washington DC: Island Press).

Samson, FB, Knopf FL, and Ostlie WR. (2004) Great Plains ecosystems: past, present, and future. Wildlife Society Bulletin 32: 6-15.
Sanford MP, and Huntly N. (2009) Selective herbivory by the Desert Woodrat (Neotoma lepida) on Joshua Trees (Yucca brevifolia). Western North American Naturalist 69: 165-170.

Shaw JH. (1995) How many bison originally populated western rangelands? Rangelands 17: 148-150.

Smith FA. (1995) Den characteristics and survivorship of woodrats (Neotoma lepida) in the eastern Mojave Desert. The Southwestern Naturalist 40: 366-372.

Sosebee RE, Churchill FM, and Green CW. (1982) Soil water depletion by yucca. Journal of Range Management 35: 774-776.

Stormer FA. (1984) Night-roosting habitat of Scaled Quail. Journal of Wildlife Management 48: 191-197.

Stubbendieck J, Nichols JT, and Butterfield CH. (1989) Nebraska range and pasture forbs and shrubs. Institute of Agriculture and Natural Resources, University of Nebraska-Lincoln, Nebraska Cooperative Extension E.C. 89-118, Lincoln, NE. 153 pp.

Thies M, and Caire W. (1990) Association of Neotoma micropus nests with various plant species in southwestern Oklahoma. The Southwestern Naturalist 35: 80-82.

Vander Wall SB. (1993) A model of caching depth: implications for scatter hoarders and plant dispersal. American Naturalist 141: 217-232.

Vander Wall SB. (1997) Dispersal of Singleleaf Piñon Pine (Pinus monophylla) by seed-caching rodents. Journal of Mammalogy 78: 181-191.

Vander Wall SB, Esque T, Haines D, Garnett M, and Waitman BA. (2006) Joshua Tree (Yucca brevifolia) seeds are dispersed by seed-caching rodents. Ecoscience 13: 539-543.

Vander Wall SB, Thayer TC, Hodge JS, Beck MJ, and Roth JK. (2001) Scatter-hoarding behavior of Deer Mice (Peromyscus maniculatus). Western North American Naturalist 61: 109-113.

Weaver JE. (1954) North American Prairie (Lincoln, NE: Johnsen Publishing Company).

Weaver JE, Albertson FW, Allred BW, and Heerwagen A. (1956) Grasslands of the Great Plains: Their Nature and Use (Lincoln, NE: Johnsen Publishing Company).

Webber JM. (1953) Yuccas of the Southwest. U.S. Department of Agriculture, Agriculture Monograph No 17, Washington DC, 97 pp.

White JA, and Geluso K. (2012) Seasonal link between food hoarding and burrow use in a nonhibernating rodent. Journal of Mammalogy 93: 149-160. 